\title{
Small Hydropower in the United States
}
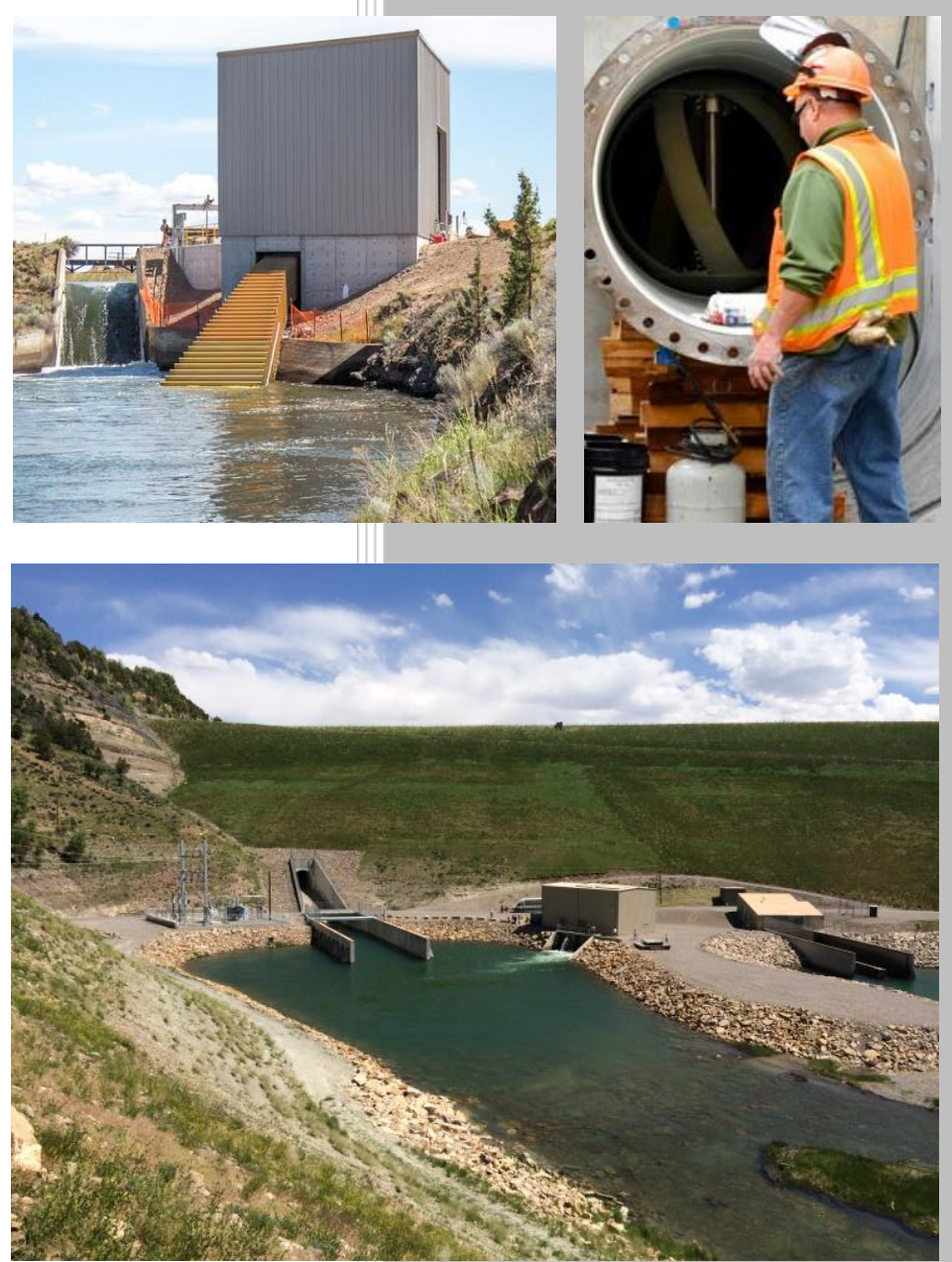

Kurt Johnson

Boualem Hadjerioua

September 2015 


\section{DOCUMENT AVAILABILITY}

Reports produced after January 1, 1996, are generally available free via US Department of Energy (DOE) SciTech Connect.

Website http://www.osti.gov/scitech/

Reports produced before January 1, 1996, may be purchased by members of the public from the following source:

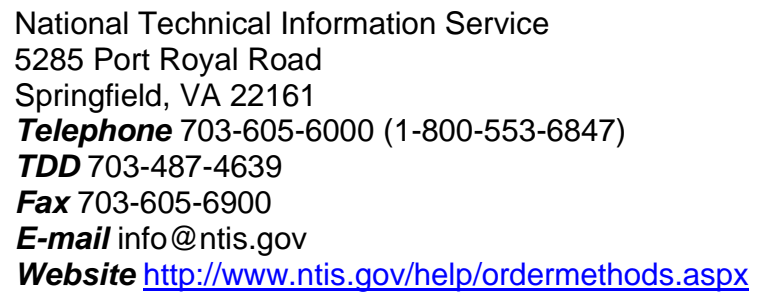

Reports are available to DOE employees, DOE contractors, Energy Technology Data Exchange representatives, and International Nuclear Information System representatives from the following source:

Office of Scientific and Technical Information

PO Box 62

Oak Ridge, TN 37831

Telephone 865-576-8401

Fax 865-576-5728

E-mail reports@osti.gov

Website http://www.osti.gov/contact.html

This report was prepared as an account of work sponsored by an agency of the United States Government. Neither the United States Government nor any agency thereof, nor any of their employees, makes any warranty, express or implied, or assumes any legal liability or responsibility for the accuracy, completeness, or usefulness of any information, apparatus, product, or process disclosed, or represents that its use would not infringe privately owned rights. Reference herein to any specific commercial product, process, or service by trade name, trademark, manufacturer, or otherwise, does not necessarily constitute or imply its endorsement, recommendation, or favoring by the United States Government or any agency thereof. The views and opinions of authors expressed herein do not necessarily state or reflect those of the United States Government or any agency thereof.

Cover photos, clockwise from top left: Monroe Drop hydro project (photo courtesy of Natel Energy); City of Portland, Oregon, hydro project (photo courtesy of Sherri Kaven, Lucid Energy); Tri-County Water hydro project at Ridgway Reservoir, Colorado (photo courtesy of Telluride Energy). 
Environmental Sciences Division

\title{
SMALL HYDROPOWER IN THE UNITED STATES
}

Kurt Johnson

Boualem Hadjerioua

Date Published: September 2015

\author{
Prepared for the \\ US Department of Energy \\ Wind and Water Program \\ Prepared by \\ OAK RIDGE NATIONAL LABORATORY \\ Oak Ridge, TN 37831-6283 \\ managed by \\ UT-BATTELLE, LLC \\ for the \\ US DEPARTMENT OF ENERGY \\ under contract DE-AC05-00OR22725
}





\section{CONTENTS}

Page

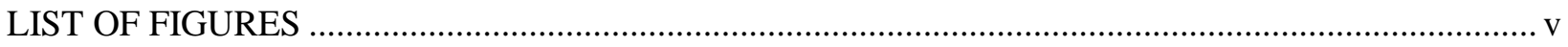

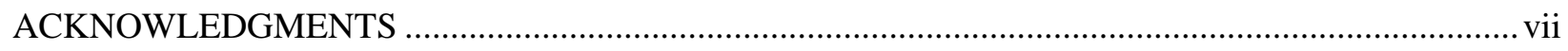

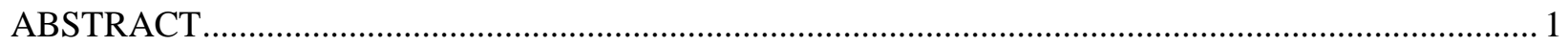

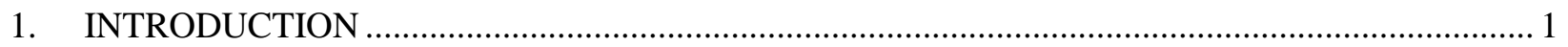

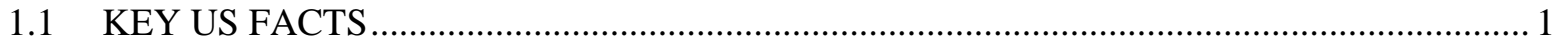

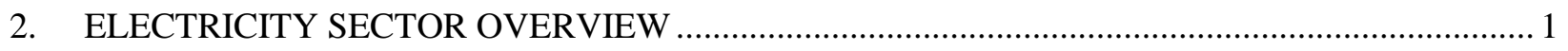

2.1 DESCRIPTION OF THE US ELECTRICITY INDUSTRY ….................................... 3

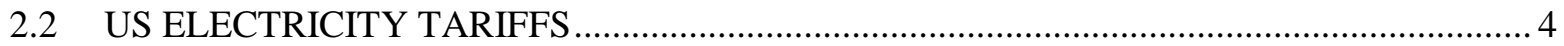

3. US SMALL HYDROPOWER OVERVIEW .................................................................. 4

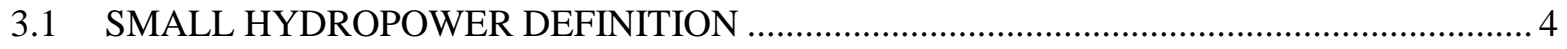

3.2 EXISTING US HYDROPOWER AND SMALL HYDROPOWER GENERATION ............... 4

3.3 GOVERNMENT POSITION ON SMALL HYDROPOWER ….......................................... 7

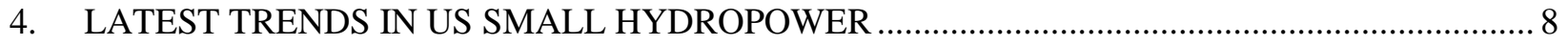

4.1 NEW SMALL HYDROPOWER RESOURCE ASSESSMENTS …................................... 8

4.2 NEW SIMPLIFIED PERMITTING FOR SMALL HYDROPOWER …............................. 9

4.3 NEW FEDERAL AND STATE FUNDING FOR SMALL HYDROPOWER ….................... 10

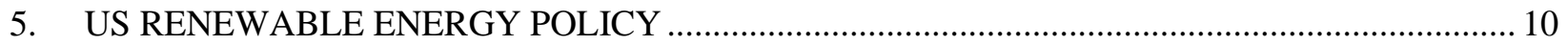

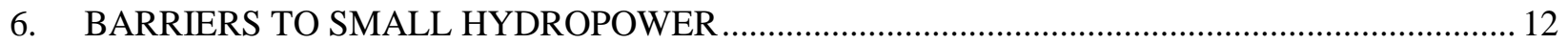

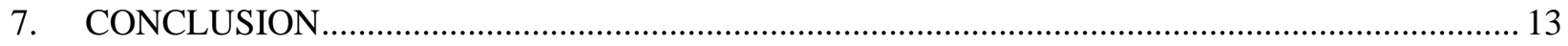

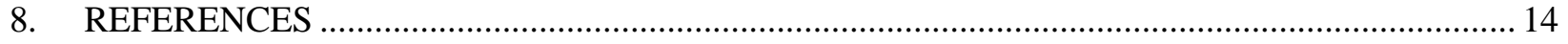





\section{LIST OF FIGURES}

Page

Fig. 1. US electricity generation by fuel source................................................................................. 2

Fig. 2. Trends in US electricity consumption. Source: US Energy Information Administration, Short-Term Energy Outlook, Washington, DC, June 2015

Fig. 3. Trends in US residential electricity prices. Source: US Energy Information

Administration, Short- $\quad$ Term Energy Outlook, Washington, DC, June 2015.

Fig. 4. Map of the US hydropower fleet. Source: R. Uria-Martinez, M. Johnson, and P.

O'Connor, $2014 \quad H y d r o p o w e r$ Market Report, DOE/EE-1195, Oak Ridge

National Laboratory, Oak Ridge, Tenn., April

2015.

Fig. 5. Size distribution of hydropower plants installed in the United States since 1950. Source:

National Hydropower Asset Assessment Program, "Existing Hydropower Assets: 2014,"

http://nhaap.ornl.gov/.

Fig. 6. Hydropower projects in the FERC and Bureau of Reclamation development pipeline by size as of December 2014. Source: R. Uria-Martinez, M. Johnson, and P. O'Connor, 2014 Hydropower Market Report, DOE/EE-1195, Oak Ridge National Laboratory, Oak Ridge, Tenn., April 2015.

Fig. 7. Locations of untapped small hydropower potential on existing NPDs. Source:

B. Hadjerioua et al., An Assessment of Energy Potential at Non-Powered Dams in the

United States, US Department of Energy, Energy Efficiency and Renewable Energy,

Washington, DC, April 2012. 8

Fig. 8. Status of RPS policies, December 2014. Source: Lawrence Berkeley National Laboratory,

Renewables Portfolio Standards Resources, http://emp.lbl.gov/rps. 



\section{ACKNOWLEDGMENTS}

The authors would like to acknowledge and express their appreciation for the following US Department of Energy (DOE) and Oak Ridge National Laboratory (ORNL) staff for their review of this report: Hoyt Battey (DOE) and Rocio Uria-Martinez (ORNL). The authors also wish to thank Lindsay George (Applegate Group), David Zayas (National Hydropower Association), and Shelaine Hetrick, the operation manager for the Water Power Program at ORNL for their review and comments. Any remaining errors in this report are the sole responsibility of the authors. 



\begin{abstract}
Small hydropower, defined in this report as hydropower with a generating capacity of up to $10 \mathrm{MW}-$ typically built using existing dams, pipelines, and canals - has substantial opportunity for growth. Existing small hydropower comprises about $75 \%$ of the current US hydropower fleet in terms of number of plants. The economic feasibility of developing new small hydropower projects has substantially improved recently, making small hydropower the type of new hydropower development most likely to occur. In 2013, Congress unanimously approved changes to simplify federal permitting requirements for small hydropower, lowering costs and reducing the amount of time required to receive federal approvals. In 2014, Congress funded a new federal incentive payment program for hydropower, currently worth approximately 1.5 cents $/ \mathrm{kWh}$. Federal and state grant and loan programs for small hydropower are becoming available. Pending changes in federal climate policy could benefit all renewable energy sources, including small hydropower. Notwithstanding remaining barriers, development of new small hydropower is expected to accelerate in response to recent policy changes.
\end{abstract}

\title{
1. INTRODUCTION
}

This report was prepared in response to a request from the United Nations Industrial Development Organization (UNIDO) and the International Center on Small Hydropower. It will be included in the World Small Hydro Development Report that is being developed to provide a global compilation of small hydropower data. This report was developed following content and length guidelines provided by UNIDO to provide consistency among reports from each country. It uses recently developed information from the authors and related sources in reports issued by Oak Ridge National Laboratory (ORNL) and the US Department of Energy (DOE), including the National Hydropower Asset Assessment report, ${ }^{1}$ the 2014 Hydropower Market Report, ${ }^{2}$ and the New Pathways report, ${ }^{3}$ as well as the Blue Gold report issued by the Hydro Research Foundation. ${ }^{4}$

\subsection{KEY US FACTS}

2015 Population: Approximately 320 million $^{5}$

Area: $9,826,675$ square kilometers ${ }^{6}$

Climate: Varies widely according to location, including arctic regions in Alaska, tropical in Hawaii, Mediterranean in California, arid in the Southwest, and temperate across much of the country.

Topography: Large central plains, hills, and low mountains in the East; mountains in the West. The highest point is Mount Denali (Alaska), which is 6,194 $\mathrm{m}$ above sea level. The lowest point is Death Valley (California), which is $86 \mathrm{~m}$ below sea level.

Rain pattern: Varies according to location.

Overview of water resources: Largest river systems based on flow volume are the Columbia River in the Northwest and the Mississippi River in the Southeast.

\section{ELECTRICITY SECTOR OVERVIEW}

In 2014, total US electricity-generating capacity was $1,003.3 \mathrm{GW}{ }^{7}$ For many years, coal has been the largest single source of US electricity supply, although recently natural gas generation has been growing rapidly, along with wind and solar. ${ }^{8}$ 
Hydropower as a percentage of total US electricity generation has been relatively stable, currently supplying about $7 \%$ of US electricity. ${ }^{9}$ Total US hydropower generation capacity has been relatively flat since 2000 , with less than a $2 \%$ total increase during that time. ${ }^{10}$

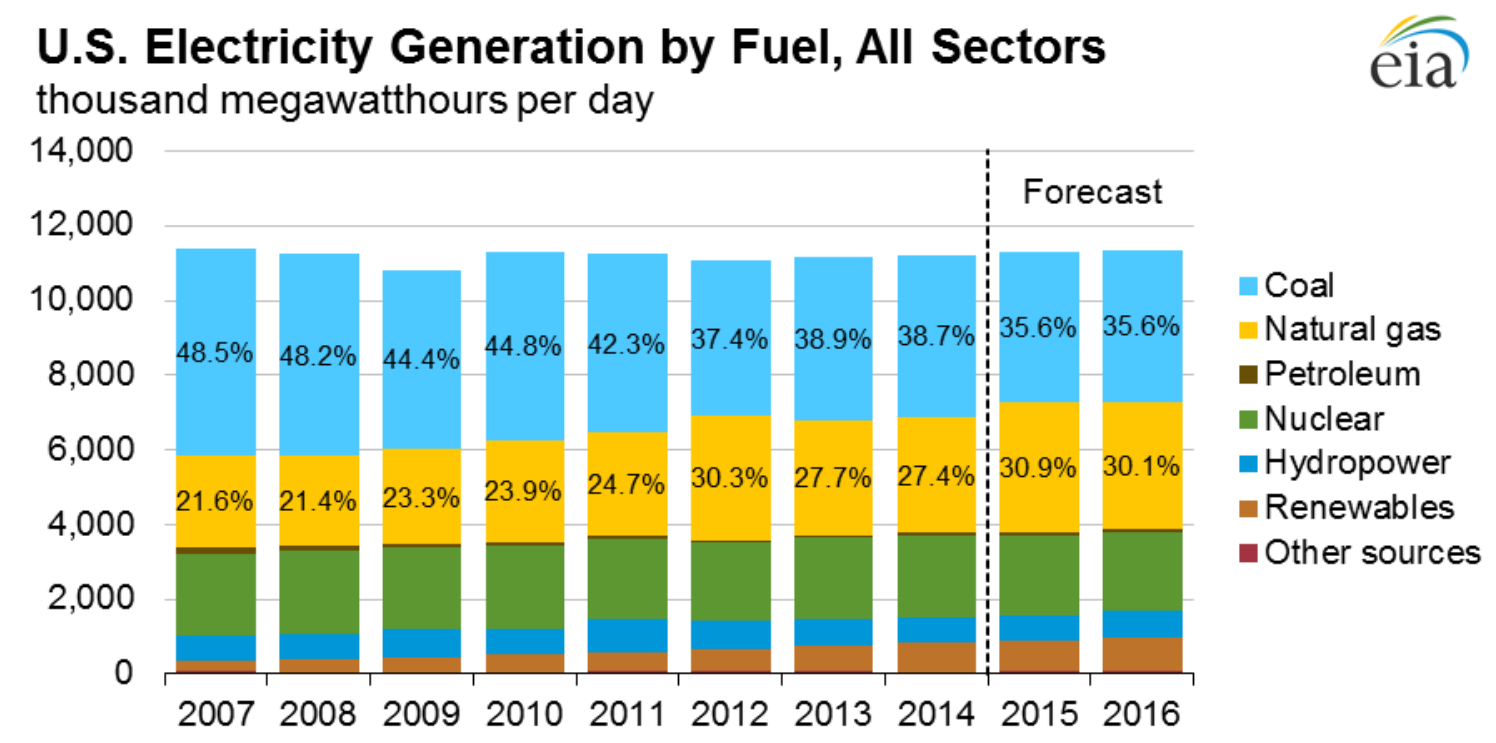

Note: Labels show percentage share of total generation provided by coal and natural gas.

Source: Short-Term Energy Outlook, June 2015.

Fig. 1. US electricity generation by fuel source. Source: US Energy Information Administration, ShortTerm Energy Outlook, Washington, DC, June 2015. ${ }^{11}$

US electricity load growth has been minimal, notwithstanding economic growth, as the US economy becomes more energy efficient. 


\section{US Electricity Consumption}

million kilowatthours per day $(\mathrm{kWh} / \mathrm{d})$

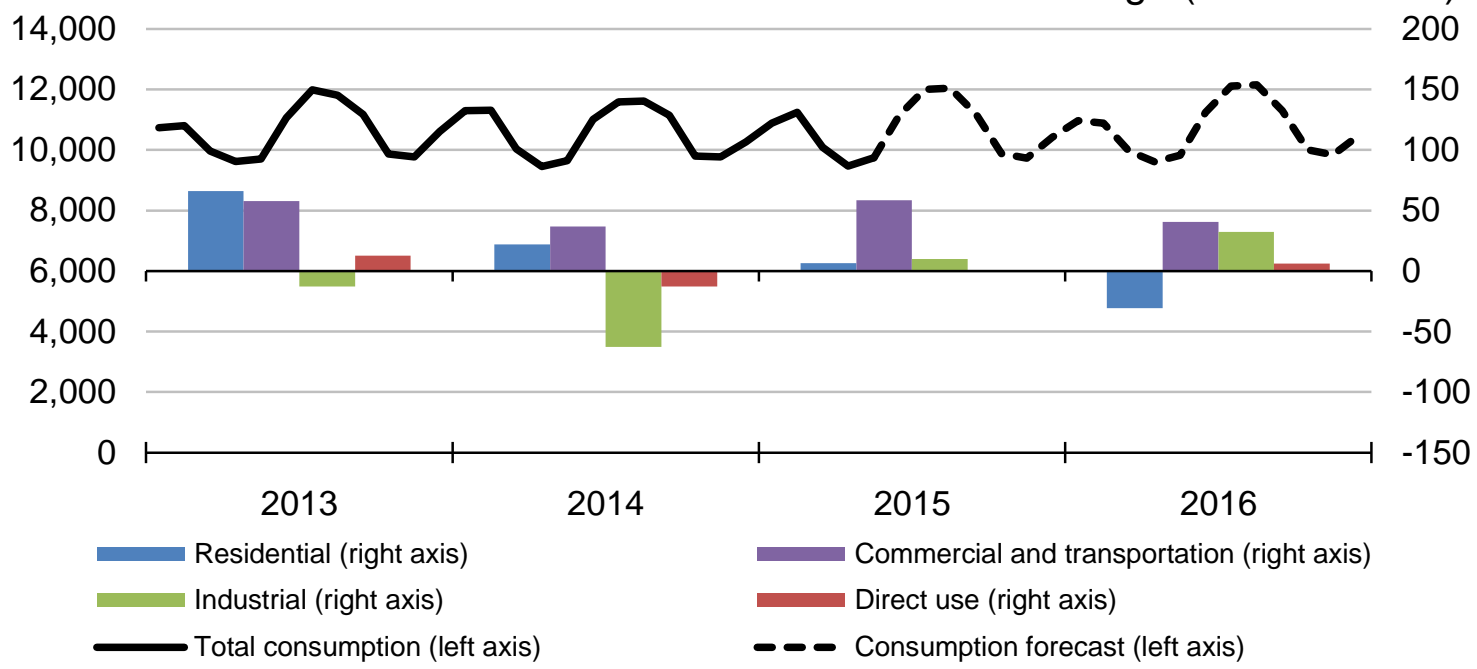

Source: Short-Term Energy Outlook, June 2015.

Fig. 2. Trends in US electricity consumption. Source: US Energy Information Administration, Short-Term Energy Outlook, Washington, DC, June 2015. ${ }^{12}$

\subsection{DESCRIPTION OF THE US ELECTRICITY INDUSTRY}

Historically, the US electricity industry has been comprised of a mix of private and public utilities that generate and deliver electricity to customers within exclusive franchise service territories; more than 3000 electric utilities operate today across the country.

More recently, some US states and regions have established competitive markets for both electricity generation and delivery. This process is often referred to as electric industry restructuring or deregulation; it has resulted in new entrants to all segments of the electricity industry, including generation, transmission, and delivery.

Because of the historically exclusive nature of utility service territories, the electric industry has been subject to a high degree of government regulation. Investor-owned utilities are regulated by the states in which they operate. Municipal utilities are operated by local governments and are overseen by local elected or appointed officials. Electric cooperatives are governed by a board of directors elected from the cooperative's membership.

In addition, the Federal Energy Regulatory Commission (FERC), an independent agency of the US government, regulates the interstate transmission of electricity. A key outcome of electric industry restructuring has been the formation of independent system operators (ISOs) that administer the transmission grid on a regional basis, including some portions of Canada. These entities were established to provide nondiscriminatory access to transmission for both electricity generators and distribution companies in competitive markets. The ISOs also perform centralized day-ahead dispatch of the generation resources in their service area to produce a least-cost production schedule for each hour of the next day, resolve gaps between generation and demand in real time, and operate ancillary service markets. The seven US-based ISOs are regulated by FERC. 
The move toward greater competition in electricity supply and delivery has fostered a shift in electricity generation sources. Environmental concerns, particularly related to airborne emissions from fossil fuelbased electricity generation sources, are also affecting utility generation choices, typically in response to regulatory requirements.

\subsection{US ELECTRICITY TARIFFS}

Electricity tariffs are a product of a utility's generation, transmission, distribution, and administrative costs, as well as return on investment in the case of investor-owned utilities. Recent electricity rates have been relatively stable with low annual growth, ${ }^{13}$ partly in response to low wholesale prices resulting from an abundance of natural gas. In December 2014, average US electricity prices were as follows: residential: 12.5 cents/kWh; commercial: 10.75 cents/kWh; and industrial: 7.01 cents/kWh. ${ }^{14}$

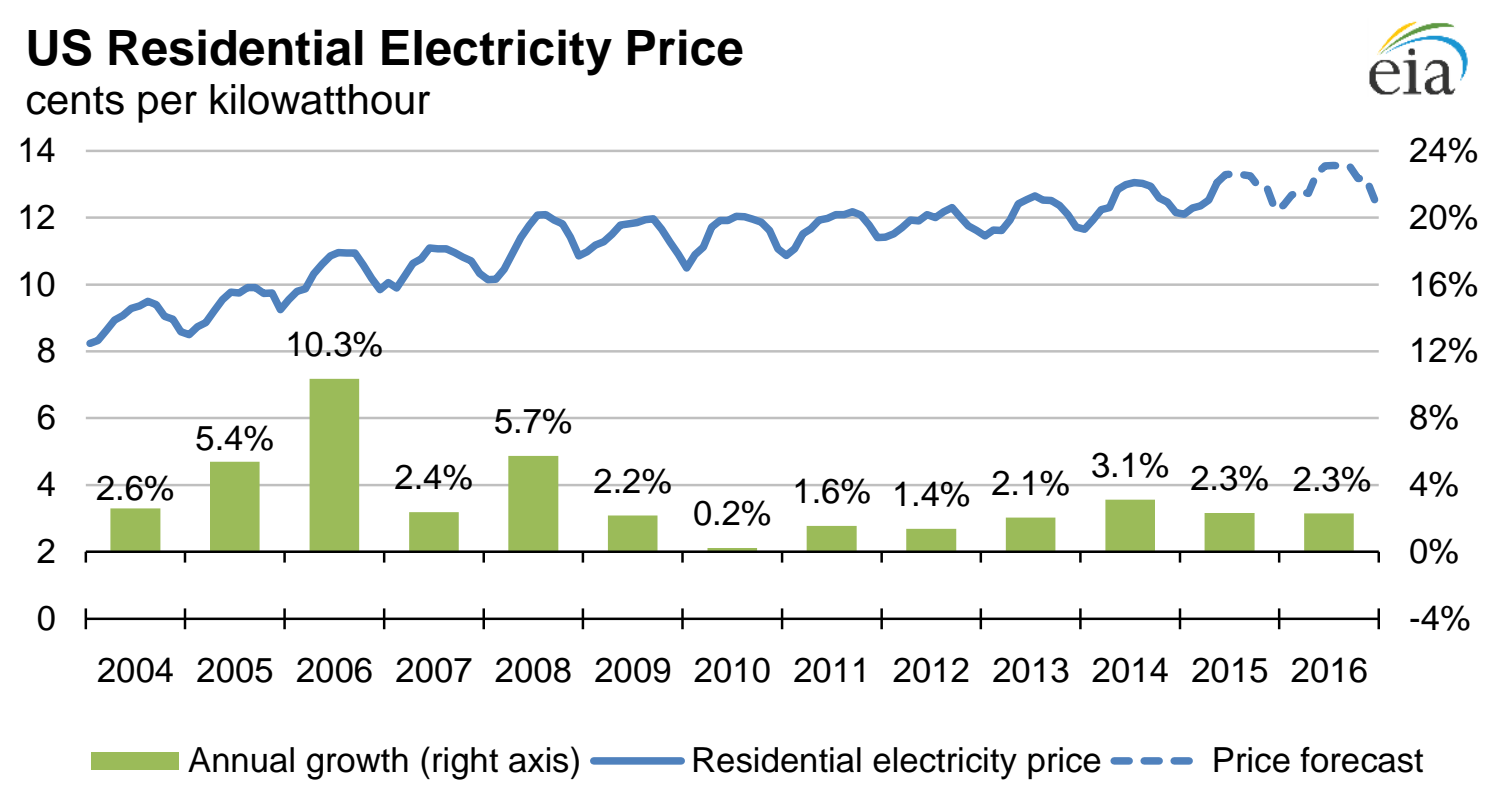

Source: Short-Term Energy Outlook, June 2015.

Fig. 3. Trends in US residential electricity prices. Source: US Energy Information Administration, ShortTerm Energy Outlook, Washington, DC, June $2015 .^{15}$

\section{US SMALL HYDROPOWER OVERVIEW}

\subsection{SMALL HYDROPOWER DEFINITION}

There is no widely agreed-upon US definition of the term "small hydropower." For this report, small hydropower is defined as hydropower up to $10 \mathrm{MW}$, which is the largest capacity that can qualify for a small hydropower exemption at FERC pursuant to the Hydropower Regulatory Efficiency Act of 2013. Small hydropower is typically built using existing infrastructure, including existing dams, canals, and pipelines.

\subsection{EXISTING US HYDROPOWER AND SMALL HYDROPOWER GENERATION}

Total US hydropower generating capacity, not including pumped storage, is approximately 80,000 MW from 2,198 hydropower plants. ${ }^{16}$ Roughly half of US hydropower capacity is located in three states: 
Washington, Oregon, and California. ${ }^{17}$ Three federal agencies - the US Army Corps of Engineers, the Bureau of Reclamation, and the Tennessee Valley Authority - own nearly half of US hydropower capacity. The 176 plants they own account for $49 \%$ of the capacity but only $8 \%$ of the plants. ${ }^{18}$

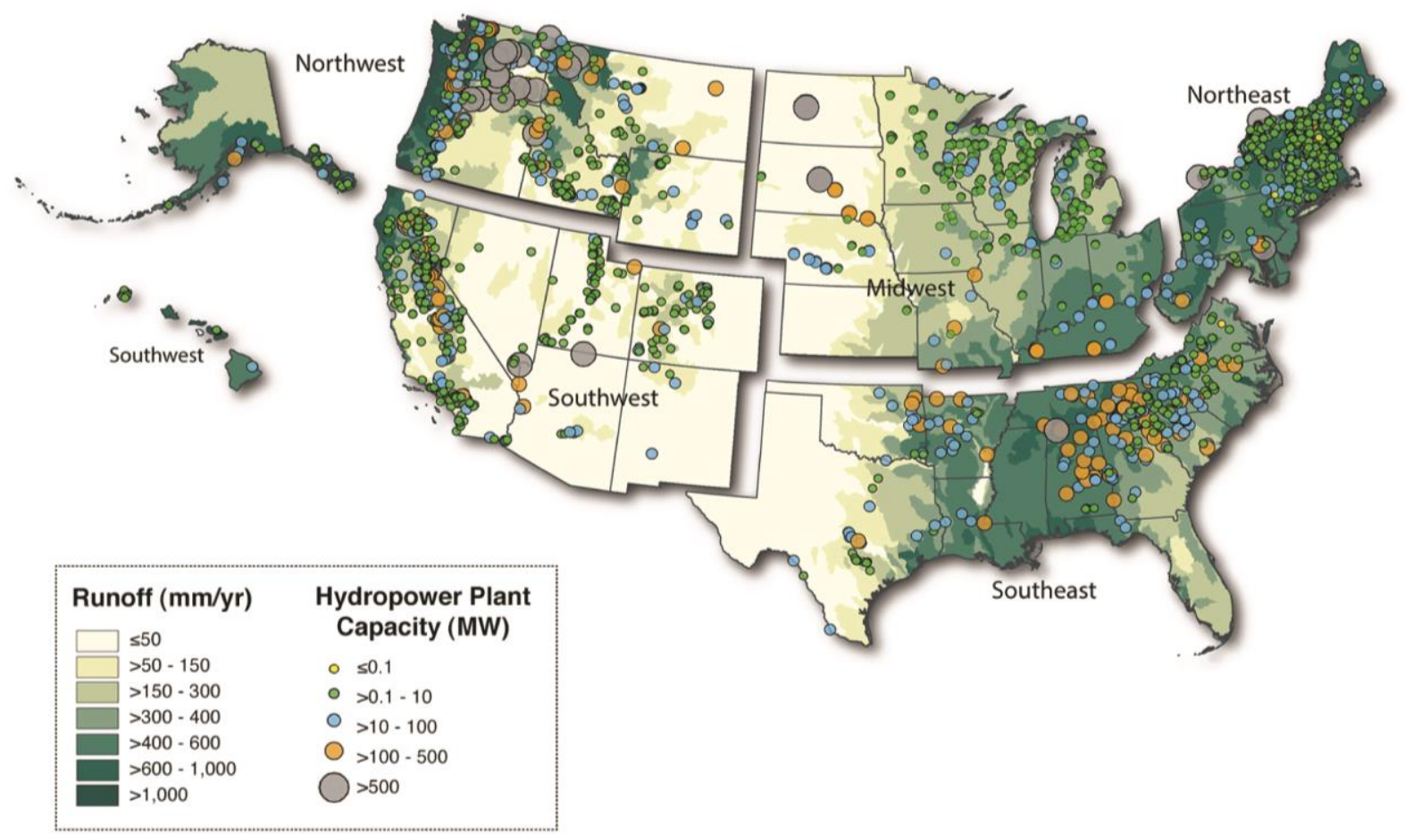

Fig. 4. Map of the US hydropower fleet. Source: R. Uria-Martinez, M. Johnson, and P. O'Connor, 2014 Hydropower Market Report, DOE/EE-1195, Oak Ridge National Laboratory, Oak Ridge, Tenn., April $2015 .^{19}$

Most of the installed US hydropower capacity comes from large projects built between 1930 and 1970 . Since the 1980s, most new hydropower capacity additions have been small, including plants built in response to the Public Utility Regulatory Policies Act (PURPA), signed into law in 1978, which opened the door to development of smaller plants. (See Sect. 5 for additional information about PURPA.)

The existing fleet of US small hydropower plants consists of 1,640 plants with a combined generating capacity of approximately 3,670 MW. ${ }^{20}$ In terms of numbers of units, most planned new hydropower development is for small projects (less than $10 \mathrm{MW}$ ). 


\section{Hydropower Plants Installed in the US 1950-2014}

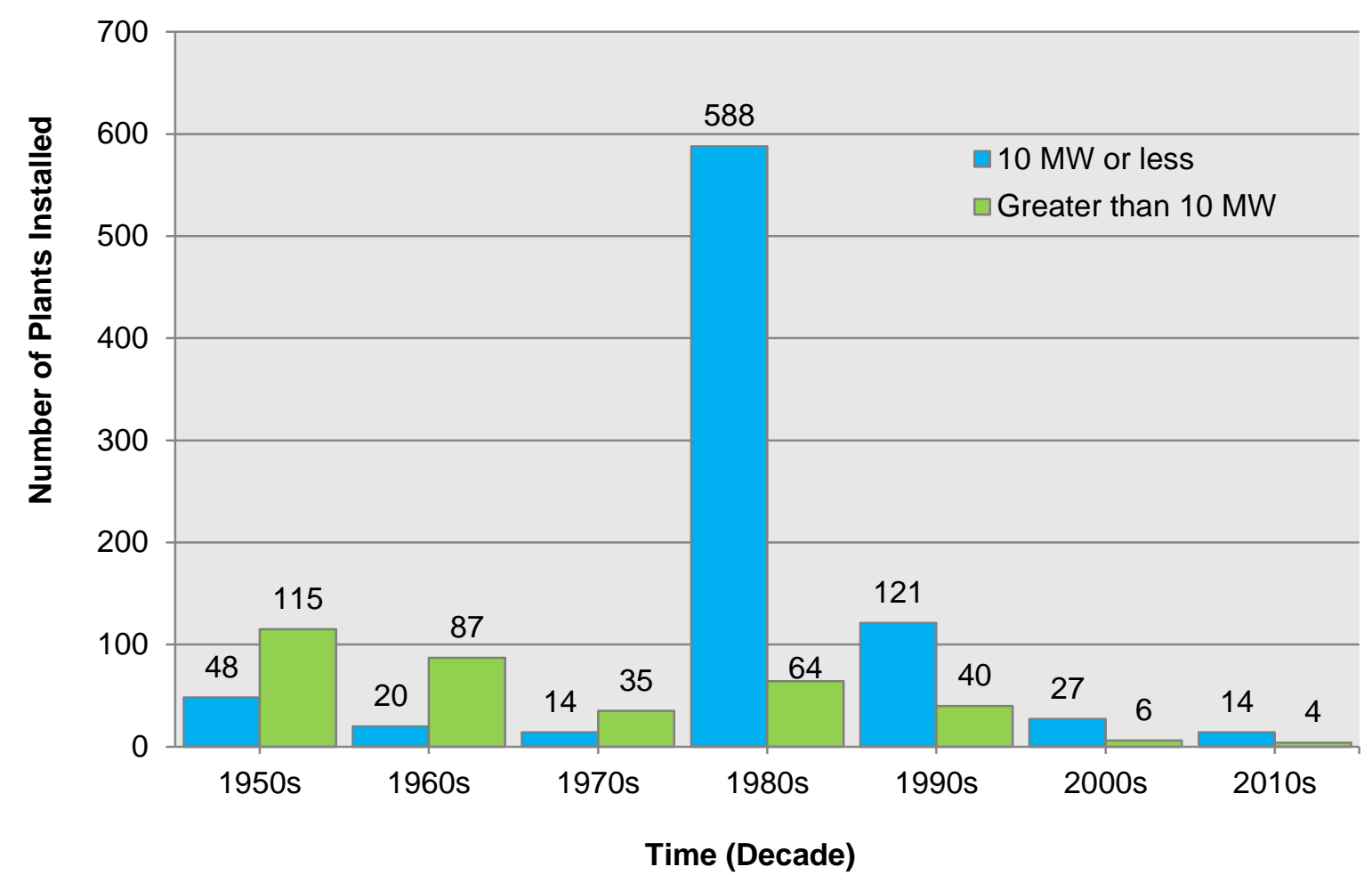

Fig. 5. Size distribution of hydropower plants installed in the United States since 1950. Source: National Hydropower Asset Assessment Program, "Existing Hydropower Assets: 2014," http://nhaap.ornl.gov/. ${ }^{21}$

Figure 6 includes projects at any stage of development in the FERC pipeline. The majority of projects are at an early stage in which project developers obtain a permit from FERC to complete feasibility studies. These "preliminary permits" confer upon the developer the exclusive right to apply for a license at a particular site within a three-year period. If that right is not exercised and an extension is not granted, the permit expires and the site can be pursued by other developers. The attrition rate between the preliminary permit phase and the next step of the development process is typically high. 


\section{Projects in the FERC Development Pipeline}

as of December 2014

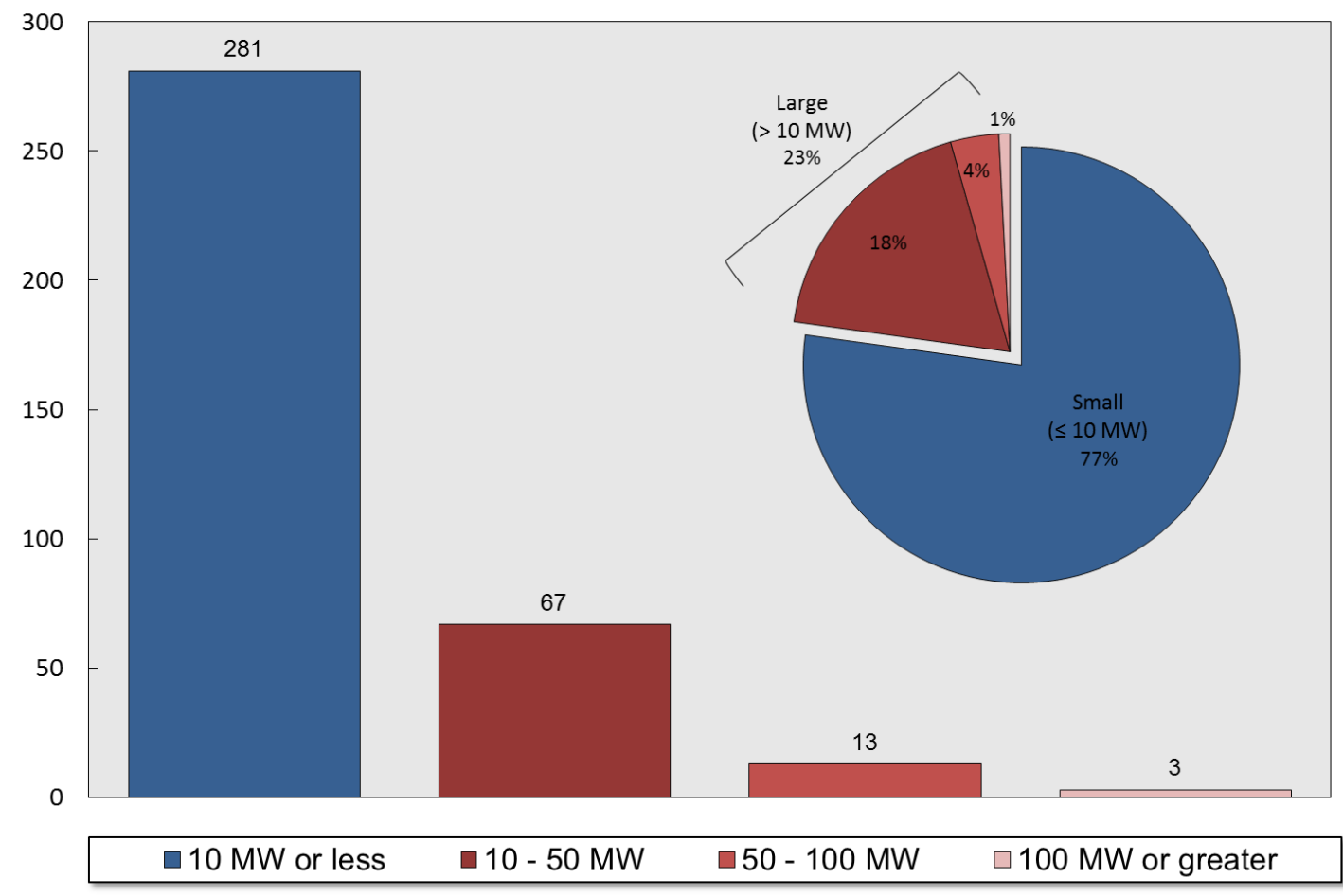

Fig. 6. Hydropower projects in the FERC and Bureau of Reclamation development pipeline by size as of December 2014. Source: R. Uria-Martinez, M. Johnson, and P. O'Connor, 2014 Hydropower Market Report, DOE/EE-1195, Oak Ridge National Laboratory, Oak Ridge, Tenn., April 2015. ${ }^{22}$

\subsection{GOVERNMENT POSITION ON SMALL HYDROPOWER}

DOE is committed to driving critical research and development efforts for small hydropower as part of its Water Power Program, which includes support for conventional hydropower, including small hydro, as well as marine and hydrokinetic technologies. In 2014, DOE announced that it was looking toward a promising future for the hydropower industry by initiating development of a long-range national Hydropower Vision, which will establish the analytical basis for a future roadmap to usher in a new era of growth in hydropower, including small hydropower.

Various state governments have developed policy and program efforts to support small hydropower, including Oregon, California, Massachusetts, Rhode Island, Vermont, Colorado, Pennsylvania, Maine, and Wyoming. Typical state initiatives include hydropower resource assessments, grant and loan funding, and efforts to improve hydropower licensing coordination between state and federal environmental agencies. For example, in 2013 a memorandum of understanding (MOU) was signed between FERC and the California State Water Resources Control Board to coordinate pre-application activities for nonfederal hydropower proposals in California. The purpose of the MOU was to coordinate procedures and schedules before FERC's review of hydropower license applications and the State Water Board's review of water quality certification applications. This collaboration is expected to reduce redundancy and streamline the issuance of environmental documents that satisfy the legal requirements of both federal and California environmental laws. 


\section{LATEST TRENDS IN US SMALL HYDROPOWER}

\subsection{NEW SMALL HYDROPOWER RESOURCE ASSESSMENTS}

Currently, only about $3 \%$ of the nation's roughly 80,000 existing dams include hydropower. The two single largest US hydropower owners - the US Army Corps of Engineers and the Bureau of Reclamation - are also the owners of a significant portion of non-powered dams (NPDs) with hydropower development potential. ${ }^{23}$ Recently completed federal and state resource assessments have highlighted the magnitude of the untapped small hydropower development opportunity. In 2012, ORNL issued an assessment of the nation's NPDs and estimated that 12,000 MW of untapped hydropower capacity was available on existing NPDs. ${ }^{24}$ Most of the untapped sites are for small hydropower, with a potential for approximately 2,556 MW of new capacity distributed across existing dams at 54,191 prospective project sites. $^{25}$

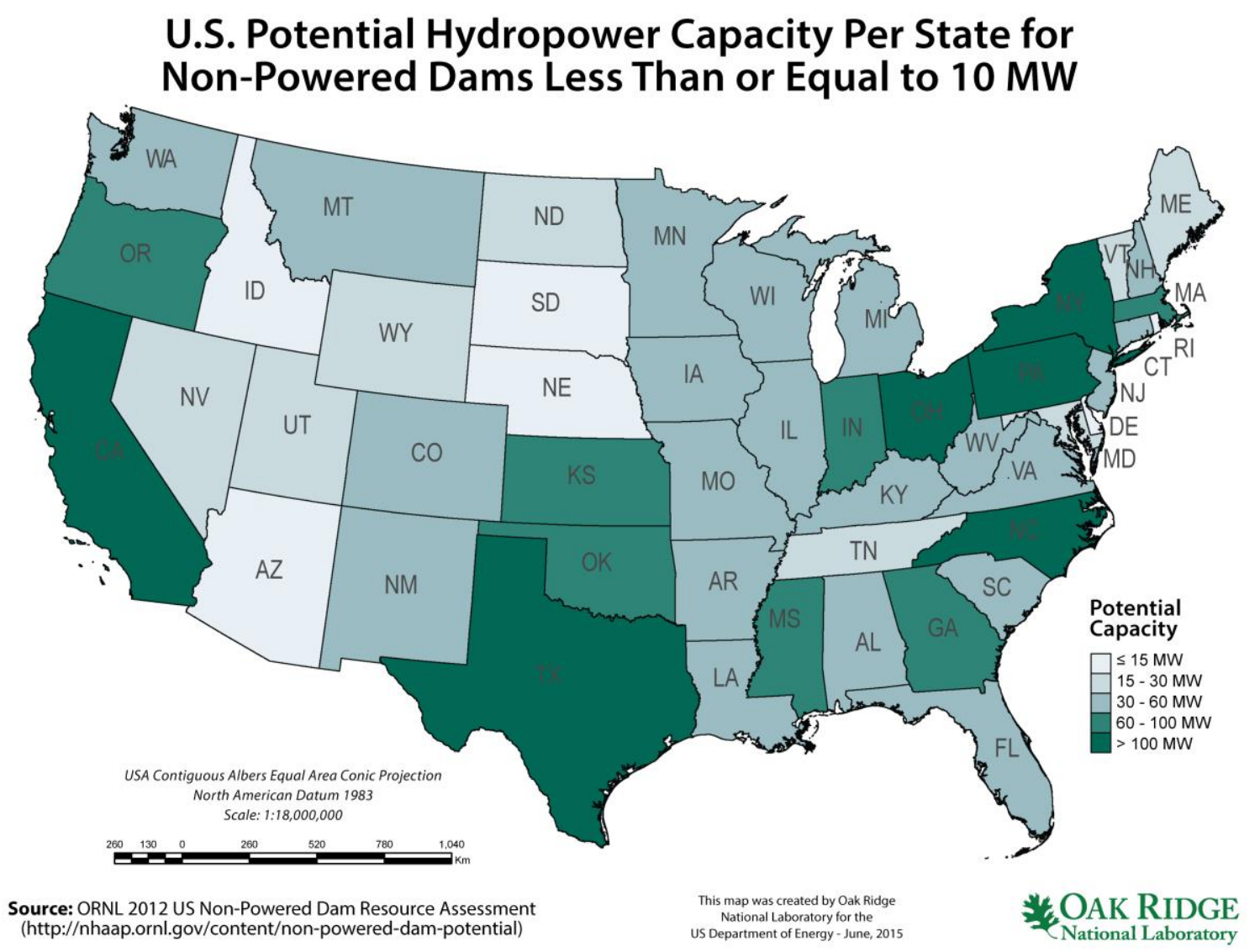

Fig. 7. Locations of untapped small hydropower potential on existing NPDs. Source: B. Hadjerioua et al., An Assessment of Energy Potential at Non-Powered Dams in the United States, US Department of Energy, Energy Efficiency and Renewable Energy, Washington, DC, April 2012. ${ }^{26}$

There has not yet been a comprehensive national assessment of untapped small hydropower generating potential that would use existing conduits (including irrigational canals, water supply pipelines, and opportunities available at water treatment plants), although some state and federal agencies have started to compile relevant data. 
A 2012 study by the US Bureau of Reclamation examined energy development potential on Reclamationowned facilities. The bureau found that 191 canals had at least some level of hydropower potential and that 70 of those sites could be considered economically viable for development. This report concluded that there are $104 \mathrm{MW}$ of potential capacity and $365 \mathrm{GWh}$ of potential generation at the 373 Reclamation canals studied. ${ }^{27}$

A 2013 study performed by the Colorado Department of Agriculture analyzed the hydropower potential of pressurized irrigation systems. The study estimated that $7 \%$ or 175,000 acres of Colorado's irrigated farmland is suitable for new, pressurized irrigation and installation of very small hydropower plants. Researchers determined that as much as $30 \mathrm{MW}$ of power could be generated from these systems. ${ }^{28}$ On the basis of those findings, the Colorado Department of Agriculture created a program to support development of agricultural hydropower.

\subsection{NEW SIMPLIFIED PERMITTING FOR SMALL HYDROPOWER}

Federal permitting requirements for small hydropower have recently been significantly simplified. In August 2013, President Obama signed into law two pieces of legislation aimed at making the regulatory process more efficient for small hydro: H.R. 267, Hydropower Regulatory Efficiency Act of 2013, and H.R. 678, Bureau of Reclamation Small Conduit Hydropower Development and Rural Jobs Act.

The Hydropower Regulatory Efficiency Act created a "regulatory off-ramp" from FERC permitting requirements for noncontroversial hydro projects on existing conduits that are less than $5 \mathrm{MW}$, provided that there are no public objections to the project during a 45-day public notice period administered by FERC. The bill also increased the FERC conduit exemption from licensing to $40 \mathrm{MW}^{*}$; directed FERC to explore a two-year licensing process for hydropower development at existing NPDs and closed-loop pumped storage projects; increased the FERC small hydro exemption from licensing from 5 to $10 \mathrm{MW}$; authorized FERC to grant developers two-year preliminary permit extensions; and directed DOE to prepare reports regarding pumped storage and conduit project opportunities.

The Bureau of Reclamation Small Conduit Hydropower Development and Rural Jobs Act authorized small (less than $5 \mathrm{MW}$ ) conduit power projects on Reclamation-owned infrastructure, while providing irrigation districts and water user associations the first right to develop hydropower projects. The bill also directed the Bureau of Reclamation to use its National Environmental Policy Act categorical exclusion process for small conduit applications.

In June 2014, the Water Resource Reform and Development Act was signed into law. According to this law, US policy that development of nonfederal hydroelectric power at US Army Corps of Engineers civil works projects - including locks and dams - shall be given priority and that Corps approval shall be completed in a timely and consistent manner. As noted previously, a majority of the nation's NPD hydropower potential is located at Army Corps dams.

Projects that are not eligible for either the recently developed "off-ramp" pursuant to the Hydropower Regulatory Efficiency Act of 2013 or one of the two types of FERC exemptions (conduit exemption or less than $10 \mathrm{MW}$ small hydropower exemption) must apply to FERC for a hydropower license. Exempted from the act are projects being constructed on Bureau of Reclamation facilities. Such facilities are subject to Reclamation's hydropower permitting process, which is referred to as a lease of power privilege.

\footnotetext{
* Obtaining a FERC exemption is typically a simpler and shorter process than obtaining a FERC license.
} 
The FERC licensing process can be lengthy and time consuming, although FERC is investigating the potential for development of a two-year licensing process in response to a directive from the Hydropower Regulatory Efficiency Act of 2013. In addition, Congress is developing comprehensive energy legislation that might include additional permitting reforms for hydropower.

\subsection{NEW FEDERAL AND STATE FUNDING FOR SMALL HYDROPOWER}

In 2014, Congress provided the initial funding allocation for the Section 242 Program, a hydropower incentive program that was created through the Energy Policy Act of 2005. The program received $\$ 3.6 \mathrm{M}$ in appropriations for 2014 and $\$ 3.9 \mathrm{M}$ for 2015 . The program's incentive for new hydroelectric generation at existing facilities is equal to about 1.5 cents $/ \mathrm{kWh}$. Facilities can receive up to $\$ 750 \mathrm{~K}$ per year for up to ten years, subject to availability through ongoing congressional appropriations. The program's congressional authorization expires in 2015; however, bipartisan legislation to reauthorize the program has been introduced in both the US House of Representatives and the US Senate.

In addition, various federal and state financing mechanisms are being created to support small hydropower. For example, the US Department of Agriculture's Rural Energy for America Program (REAP) has started providing support for small hydropower, including renewable energy project grants that support up to $25 \%$ of project costs with a maximum of $\$ 500 \mathrm{~K}$. Eligible REAP grant applicants are typically small rural businesses.

Various states have developed financing programs specific to small hydropower. The Colorado Water Conservation Board modified its existing water infrastructure financing program to create a hydropower loan program that can finance construction of hydropower projects with loan terms of 30 years at an interest rate of $2 \%$. The $8 \mathrm{MW}$ hydropower project at Ridgway Reservoir in Western Colorado (pictured on the front cover) - completed in June 2014 — was made possible by a \$15M loan through the Colorado loan program.

\section{US RENEWABLE ENERGY POLICY}

The early history of US renewable energy use, primarily hydropower, was tied to the availability and proximity of natural resources and means of production such as water wheels for grinding mills. Later, hydropower development became associated with large public works projects, including the Tennessee Valley Project and water projects undertaken by the Bureau of Reclamation and the US Army Corps of Engineers.

It was not until the 1970s that the federal government began to craft policies specifically for development of the nation's renewable energy resources.

PURPA, signed into law in 1978, opened the door to competition in the US electric power industry, particularly in the generation sector. PURPA conferred special rate and regulatory treatment on a new class of generators known as "qualifying facilities" or QFs, which were comprised of cogeneration facilities and small power-production facilities, with the latter defined as facilities generating $80 \mathrm{MW}$ or less using a renewable energy source (hydro, wind, solar, biomass, waste, or geothermal). ${ }^{29}$ PURPA required electric utilities to interconnect with and purchase power from QFs at the utility's "avoided cost," defined as the cost that the utility would otherwise incur in either generating the power themselves or procuring power from other sources.

More than 25 years later, in the Energy Policy Act of 2005, Congress made an important modification to PURPA, providing relief from PURPA's mandatory purchase obligation to utilities if FERC determines that QFs have nondiscriminatory access to the market. In this context, FERC determined that an ISO 
generally provides a sufficiently competitive market structure to support elimination of the PURPA purchase requirement for utilities operating within the ISO. At the same time, however, FERC established a rebuttable presumption that QFs with a net capacity of $20 \mathrm{MW}$ or less ("small QFs") do not have nondiscriminatory access to wholesale markets; thus the PURPA purchase obligation for utilities remains in force for small QFs ${ }^{30}$ making it possible for small hydropower generators to secure a utility power purchase agreement.

The federal government has previously enacted tax incentives to spur renewable energy development, including the production tax credit (PTC) and investment tax credit, both of which have expired for hydropower and other technologies. Small hydro has also been eligible for federal accelerated depreciation tax treatment, and some states offer tax incentives and exemptions. Hydropower, however, has historically received unequal treatment in federal tax incentives - for example, receiving half the value that wind does under the PTC.

Individual US states have adopted policies to encourage renewable energy development. The most prominent of these policies has been the adoption of a renewables portfolio standard (RPS). An RPS is a market-based policy that requires electric utilities and other retail electricity suppliers to supply a minimum percentage of their electricity sales from eligible renewable energy sources. Generally, the renewable energy is procured as wholesale purchases through competitive market solicitations.

As of the end of 2014, 29 states and the District of Columbia had instituted RPS policies, covering 56\% of total US retail electricity sales. ${ }^{31}$ In 2015, California Governor Jerry Brown announced a goal to raise the state's RPS target from 33\% in 2020 to $50 \%$ in 2030; Vermont Governor Peter Shumlin signed into law a bill that requires the state's utilities to source 55\% of their sales from renewables in 2017, rising to 75\% by 2032; and Hawaii Governor David Ige signed legislation making Hawaii the first state to adopt a $100 \%$ RPS, with the plan to reach that goal by 2045.

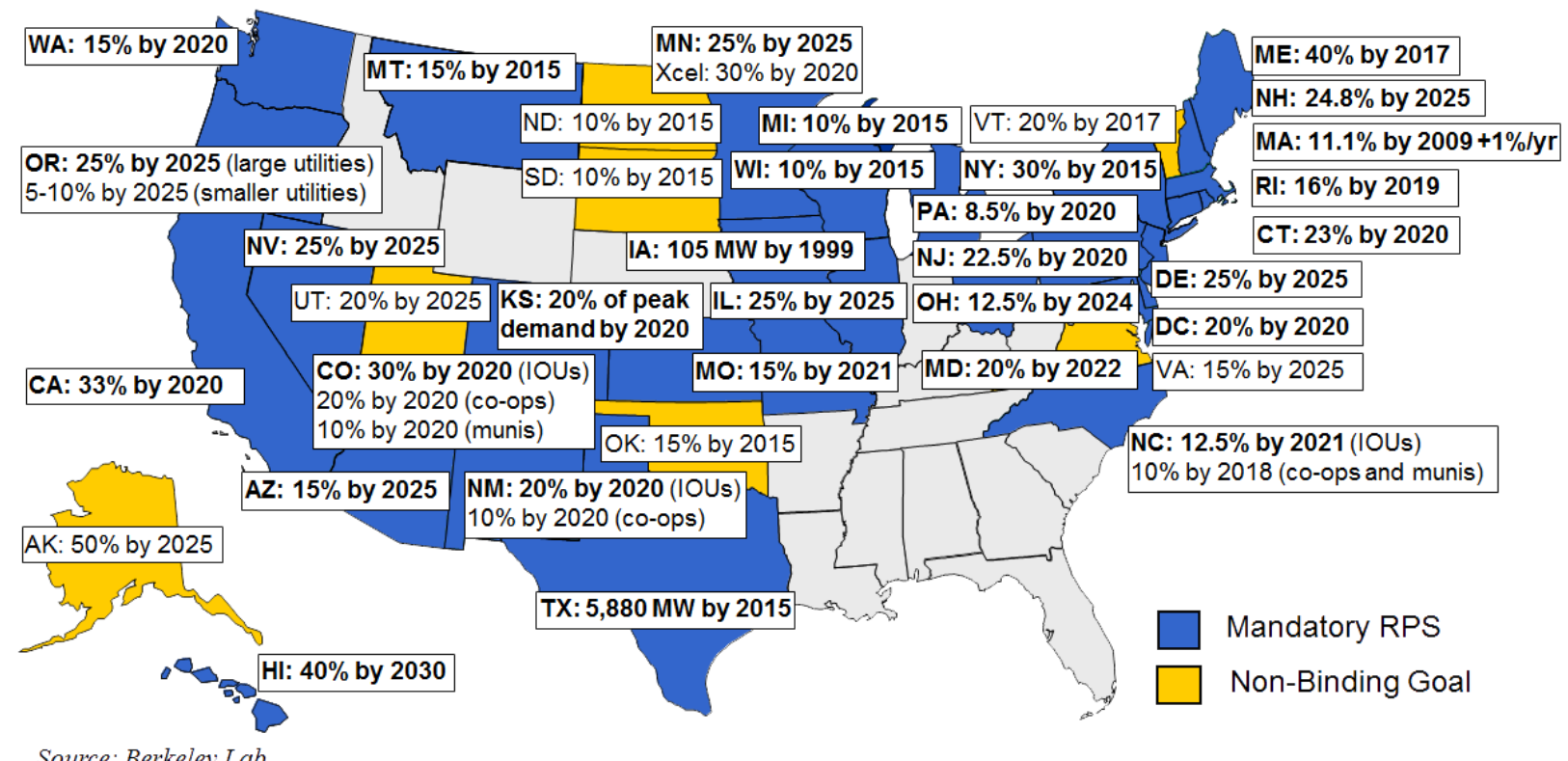

Fig. 8. Status of RPS policies, December 2014. Source: Lawrence Berkeley National Laboratory, Renewables Portfolio Standards Resources, http://emp.lbl.gov/rps. ${ }^{32}$

Small hydro projects are typically RPS eligible, although large hydro projects are often excluded from RPS eligibility. Common hydropower restrictions for RPS eligibility include restrictions based on 
capacity, type, and environmental sustainability criteria. One environmental standard is the Low Impact Hydropower Institute certification standard, used for RPS eligibility in a variety of states. ${ }^{33}$ Many RPS policies also have vintage requirements for "new" development, which can disqualify hydro production from RPS eligibility.

A feed-in tariff (FIT) is another policy that can be used for incentivizing electricity procurement from smaller renewable energy generators. A FIT provides a guaranteed payment stream at a fixed price for the renewable generator. Some states have adopted FIT-type programs. For example, California has adopted a renewable energy FIT for renewable generators that produce up to $3 \mathrm{MW}$, and Vermont offers a FIT for eligible resources that produce less than $2.2 \mathrm{MW} .^{34}$

Small hydropower systems installed adjacent to a local electricity load can typically take advantage of net energy metering (NEM). Under a NEM agreement, generated electricity is used directly by an adjacent facility; any excess generation can be exported to the utility grid for later use with the generator receiving a one-for-one credit at full retail value for any electricity generated on-site. Many US states have some form of NEM requirement in effect, providing a potent economic incentive for distributed renewable energy generation, including small hydropower. ${ }^{35}$

In addition, state government policies promoting retail electricity competition have resulted in new renewable energy development. Beginning in the late 1990s, restructured electricity markets gave consumers the opportunity to choose the source of their power, which has led many customers to purchase power directly from renewable energy providers. Increasingly, customers are seeking to obtain their electricity from sources with minimal environmental impacts. Large companies and government entities are seeking out direct investments or purchases of renewable energy as an element of their environmental sustainability commitments. For example, Apple is purchasing the output from the Monroe Drop hydro project (pictured on the front cover) in eastern Oregon, which is harnessing untapped power that has been flowing through an irrigation canal for more than 60 years. ${ }^{36}$

Taken together, state RPS policies and the voluntary purchase market have been responsible for the bulk of new US renewable development during the past decade. ${ }^{37}$

Federal policies to address climate change are likely to drive additional renewables deployment in the future. In June 2014, the US Environmental Protection Agency (EPA) issued a proposal to regulate $\mathrm{CO}_{2}$ emissions from existing power plants under Section 111(d) of the Clean Air Act. ${ }^{38}$ If implemented, the EPA's Clean Power Plan would cut carbon pollution from the power sector by $30 \%$ from 2005 levels by 2030. The US Energy Information Administration (EIA) has estimated that renewable energy would play a critical role in achieving these reductions under a range of different market conditions and policy assumptions. According to EIA, the rule could spur deployment of as much as $174 \mathrm{GW}$ of additional renewable energy generation by $2040 .^{39}$

\section{BARRIERS TO SMALL HYDROPOWER}

Despite significant changes in recent years, developers of small hydropower still face barriers, including the following:

Lack of comprehensive information regarding appropriate sites. Although federal agencies have recently completed nationwide hydropower resource assessments for existing NPDs, there has not yet been a comprehensive assessment regarding conduit opportunities, including canals and pipelines.

Risk aversion to new technology. Owners of possible conduit hydro sites, usually water agencies, are typically cautious and risk adverse with respect to the water systems for which they are responsible. There 
are relatively few existing conduit hydro installations in the United States, and many water agencies have no understanding of available small hydropower technologies. Many newer, more innovative and costcompetitive small hydropower technologies that offer a potential solution to high project costs do not necessarily have long operational track records.

Lack of standardized technology. Because relatively few conduit hydropower projects have been developed, there are few standard designs. Every conduit system is typically custom engineered, with associated high engineering costs.

Lengthy permitting. Notwithstanding successful recent federal reform efforts related to small conduit hydropower, there remain significant permitting challenges associated with small hydropower development on existing NPDs.

Electrical interconnection. Uncertainty in the cost, timing, and technical requirements of grid interconnection can be challenging for small hydropower and other distributed energy resources. Interconnection processes can be expensive and time consuming, with timetables that are not always consistent with the needs of small hydropower developers.

Electrical inspection. Because very few small hydropower projects are installed each year, most electrical inspectors are not familiar with them, and it can be difficult to secure electrical inspection approval for very small plants that are net metered. Small hydropower is not addressed in the National Electrical Code. The US small hydropower industry is not yet large enough to support mass manufacturing of standardized products that have completed independent certification. Costs associated with postmanufacture, in-thefield product testing and approval to ensure product safety can adversely affect project economic feasibility.

State and local policy issues. Barriers to small hydropower development can come from state and local regulatory policies, including regulatory issues associated with water quality certifications, as well as other state and local environmental requirements.

Financing. Small hydropower can experience financing challenges because of high upfront costs, lengthy permitting processes for existing dam projects, variable hydrology, and other project risks.

\section{CONCLUSION}

Notwithstanding barriers and challenges, small hydropower development is expected to accelerate in response to recent initiatives, including studies highlighting the magnitude of untapped US small hydro potential, new streamlined federal permitting processes, and new financial incentives. In many cases, small hydropower development can be achieved with minimal impact, supporting the nation's economic and environmental goals without requiring additional diversions from existing natural waterways. 


\section{REFERENCES}

1 B. Hadjerioua et al., National Hydropower Asset Assessment Project, Final Report 2010, Oak Ridge National Laboratory, Oak Ridge, Tenn., December 2010.

2 R. Uria-Martinez, M. Johnson, and P. O’Connor, 2014 Hydropower Market Report, DOE/EE-1195, Oak Ridge National Laboratory, Oak Ridge, Tenn., April 2015.

3 N. Bishop et al., New Pathways for Hydropower: Getting Hydropower Built-What Does It Take?, ORNL/TM-2015/48, Oak Ridge National Laboratory, Oak Ridge, Tenn., January 2015.

4 K. Johnson, Blue Gold: Building New Hydropower with Existing Infrastructure, Hydro Research Foundation, Evergreen, Colo., April 2015.

5 US Census Bureau, http://www.census.gov/.

6 US Central Intelligence Agency, The World Factbook, https://www.cia.gov/library/publications/theworld-factbook/.

7 US Energy Information Administration, Annual Energy Outlook 2015, DOE/EIA-0383(2015), Washington, DC, April 2015.

8 Ibid.

${ }^{9}$ R. Uria-Martinez, M. Johnson, and P. O'Connor, 2014 Hydropower Market Report, DOE/EE-1195, Oak Ridge National Laboratory, Oak Ridge, Tenn., April 2015.

10 US Department of Energy, 2013 Renewable Energy Data Book, National Renewable Energy Laboratory, DOE/GO-102014-4491, December 2014.

11 US Energy Information Administration, Short-Term Energy Outlook, Washington, DC, June 2015.

12 Ibid.

13 Ibid.

14 US Energy Information Administration, Electric Power Monthly: with Data for December 2015, Washington, DC, February 2015.

15 U.S. Energy Information Administration, "Short Term Energy Outlook," Washington, DC, June 2015.

16 R. Uria-Martinez, M. Johnson, and P. O'Connor, 2014 Hydropower Market Report, DOE/EE-1195, Oak Ridge National Laboratory, Oak Ridge, Tenn., April 2015.

17 Ibid.

18 Ibid.

19 Ibid.

20 B. Hadjerioua et al., National Hydropower Asset Assessment Project, Final Report 2010, Oak Ridge National Laboratory, Oak Ridge, Tenn., December 2010.

21 National Hydropower Asset Assessment Program, "Existing Hydropower Assets: 2014," http://nhaap.ornl.gov/. 
22 R. Uria-Martinez, M. Johnson, and P. O'Connor, 2014 Hydropower Market Report, DOE/EE-1195, Oak Ridge National Laboratory, Oak Ridge, Tenn., April 2015.

23 Ibid.

24 B. Hadjerioua et al., An Assessment of Energy Potential at Non-Powered Dams in the United States, US Department of Energy, Energy Efficiency and Renewable Energy, Washington, DC, April 2012.

25 Ibid.

26 Ibid.

27 M. Pulskamp, Site Inventory and Hydropower Energy Assessment of Reclamation-owned Conduits: Supplement to the "Hydropower Resource Assessment at Existing Reclamation Facilities Report, US Bureau of Reclamation, Denver, Colo., March 2012.

28 K. Johnson and L. George, Recommendations for Developing Agricultural Hydropower in Colorado, Colorado Department of Agriculture, Denver, Colo., December 2013.

29 See http://www.ferc.gov/industries/electric/gen-info/qual-fac/what-is.asp.

30 See FERC Order 688: http://www.ferc.gov/whats-new/comm-meet/101906/E-2.pdf.

31 Galen Barbose, Lawrence Berkeley National Laboratory, "Renewables Portfolio Standards in the United States: A Status Update," Presentation at the Renewable Energy Markets conference, December 2014. See http://emp.lbl.gov/sites/all/files/2014\%20REM.pdf.

32 Lawrence Berkeley National Laboratory, "Renewables Portfolio Standards Resources.” See http://emp.lbl.gov/rps.

33 See www.lowimpacthydro.org.

34 See http://www.nrel.gov/tech_deployment/state_local_governments/basics_tariffs.html.

35 See http://www.dsireusa.org/.

36 See http://www.cnbc.com/id/102748592, accessed June 12, 2015.

37 J. Heeter et al., Status and Trends in the U.S. Voluntary Green Power Market (2013 Data), NREL/TP-6A20-63052, National Renewable Energy Laboratory, Golden, Colo., November 2014. See http://www.nrel.gov/docs/fy15osti/63052.pdf .

38 US Environmental Protection Agency, Carbon Pollution Emission Guidelines for Existing Stationary Sources: Electric Utility Generating Units (Proposed Rule), 79 Fed. Reg. 34,830, June 18, 2014.

39 See http://www.eia.gov/todayinenergy/detail.cfm?id=21532. 